\title{
Retailers' Responsibility towards Consumers and Key Drivers of Their Development in Poland
}

\author{
Grażyna Śmigielska * and Renata Oczkowska \\ Cracow University of Economics, Rakowicka 27, 31-510 Kraków, Poland; oczkowsr@uek.krakow.pl \\ * Correspondence: smigielg@uek.krakow.pl; Tel.: +48-12-2935283 \\ Academic Editor: Rajesh Manchanda \\ Received: 15 October 2016; Accepted: 11 January 2017; Published: 14 January 2017
}

\begin{abstract}
Multinational retailers are now very powerful and their activities could influence whole economies. In this paper, we investigate why they engage in corporate social responsibility (CSR) practices towards consumers, how it fosters sustainable development, and what the role of institutions are in the process of developing CSR strategies. Changes that have taken place in Poland since 1989, when the transition process into a market economy started, constituted an excellent research field due to the fact that the retail market was not saturated at the beginning, consumers were only slightly protected by the law, and there were no institutions promoting the implementation of social responsibility standards by companies. Research involving analysis of secondary data drawn from retailers' websites, CSR reports, and published data relating to the CSR institutions allowed the following: (1) identification of three stages of development in consumers' conception of CSR characterized by the immoral, amoral, and moral management; (2) showing that these activities have a business case; and (3) explaining the role of institutions and competition in this process. It is also shown how multinational retailers could contribute to the sustainable development of less mature markets in which they invest.
\end{abstract}

Keywords: corporate social responsibility; consumers; multinational retailers; institutions; sustainable development; Poland

\section{Introduction}

Corporate social responsibility (CSR) is now a very much debated issue. It is relevant to many disciplines, such as politics, philosophy, and economics. In economics, the focus is on the economic justification of spending money on CSR activities which involve inter alia sponsorship, charity, cause-related marketing, and protecting the environment. The large international companies spend a lot of money on CSR, reporting it and making the public aware of what they do. It raises the question of whether the large, multinational companies are really "responsible" or if they are just forced to behave in this way and what the main impetus for CSR is. These questions could be addressed by analysing behaviour in new, emerging markets.

Poland is one of the former communist countries in Europe which, after the political changes in 1989, was very attractive to foreign investors. The most visible opportunities to the public were investments in retailing where new (for that market) forms like hypermarkets, supermarkets, discount stores, organized as chains, started to operate. On the one hand, they were very welcome because they brought a new, high quality of retail service, but on the other hand, they were criticized for unfair behaviour towards employees, consumers, and suppliers. It took a few years to implement CSR standards similar to those in well-developed countries.

Retailers' attitude towards CSR is very important due to their proximity to consumers, as well as the fact that they often have a dominant position in the distribution channels. These retailers are not only responsible for the selling process but they also advertise heavily and control the manufacturing 
process, which usually takes place in the case of their own-brand products. The focus here is on traditional retailers, although the growth of Internet sales is the new, important challenge for statutory regulations and the CSR of e-commerce retailers.

Contemporary interest in CSR is stimulated by its relation to the concept of sustainable development (SD) which has become one of the predominant macroeconomic drivers. This concept was introduced for the first time by the World Commission on Environment and Development in 1987 and it was defined as "Development which meets the needs of current generations without compromising the ability of future generations to meet their own needs" [1] (p. 11). This means not only counteracting degradation of the environment, but also meeting the needs of society as a whole (e.g., reducing destitution and poverty), setting up the market system based more on cooperation than competition, as well as in opposing degradation of cultural variety and tradition [2] (p. 81). Although it is a macroeconomic concept, it influences companies' strategies by its impact on consumer purchasing decisions. A Nielsen report [3] (p. 5) published in 2015 reveals that key drivers on consumer purchasing decisions involve characteristics related to sustainability such as their trust in the company, health and wellness benefits delivered by the product, or fresh, natural, and/or organic ingredients.

The aim of this paper is to identify the main forces driving the process of establishing CSR practices towards consumers by multinational retailers in Poland. We put forward a similar question to Baechler [4] who asked "why CA [corporate actors] adopts such CSR or SD strategies" and "how they implement them", and to Sahlin-Andersson [5] asking "what is CSR and for what?" but our methodology differs in the following manner: we obtained our initial inspiration from the criticism of corporate social responsibility in the developing world [6]. The way we analyse the problem fits into the research paradigm devoted to investigating trends in corporate social responsibility conveyed by Carroll [7,8], Carroll and Shabana [9], and the role of multinational CSR practices in creating value [10], particularly in the case of international retailers [11]. The focus of our research is on retailers' CSR practices towards consumers. The retail sector draws more and more scientists' attention whereas, to the best of our knowledge, there are not many works describing retailers' CSR practices towards consumers. Our paper is one attempt to bridge that gap.

The research methodology used in preparing this article is qualitative; desk research methods, mainly thematic analysis, were applied for selecting and surveying relevant literature; additionally, the method proposed by Moreno and Capriotti [12] was used in order to draw fact-based evidence from websites of multinational retailers' headquarters and Polish branches, institutions promoting CSR practices, and was further corroborated with the authors' personal experience with the respective companies. Reference is also made to how CSR commitments and practices are approached in business reporting. The methodology of longitudinal case study is based on Pettigrew's principles [13].

The article is structured as follows: in the next section, the conceptual issues pertaining to CSR of retailers towards consumers are examined in the light of various approaches from the international literature to date (e.g., shareholder theory, stakeholder theory), with an emphasis on its progression towards maturation. To identify possible factors influencing the development of CSR in Poland, some theoretical approaches from institutional theory and the theory of developing sustainable competitive advantage, which have been tested in practice, are presented. Then, the situation in Poland is examined, and relevant examples drawn from the reality of the retail sector discussed, starting from the early post-communist transition period up to the present day, as well as the development of CSR towards consumer practices in Tesco-the multinational retailer being among the leading companies on the Polish market-are analysed by searching Tesco Poland reports on CSR. Finally, the methodology and results are discussed. In this section, some limitations of the research and further possible developments are suggested as well.

In this paper, we find that social responsibility activities towards consumers of multinational retailers operating in Poland have a business case. Their development cannot be explained solely by the existence of institutions fostering them and pressure from the main stakeholders, but the theories of gaining sustainable competitive advantage should also be involved in the analysis. Three stages 
of multinational retailers' CSR practices towards consumer development in Poland, which could be characterised as immoral, amoral, and moral management, are identified.

\section{Main Factors Influencing Development of the CSR towards Consumer Practices Development}

\subsection{CSR and Corporate Performance Viewed from Different Theoretical Approaches}

The discussion about whether companies should engage in CSR activities can be traced to the nineteenth century [14]. This problem became very controversial in the middle of the twentieth century. At that time, it was thought that companies' engagement in solving social problems had a negative impact on profits, and economists like Bowen [15] and Friedman [16,17] held different views on whether companies should undertake CSR activities. Friedman's view was supported by Levitt [18], a specialist in marketing management, who warned business against engaging in social responsibility [9].

This discussion coincided with the spread of stakeholder theory by Freeman [19], and Donaldson and Preston [20], which emphasizes company responsibility towards all stakeholders (not only shareholders), the need for their satisfaction, and the necessity of balancing the expectations of various interests, as pointed out by De Wit and Meyer [21]. As pointed out in Carroll's definition of CSR, "The social responsibility of business encompasses the economic, legal, ethical, and discretionary expectations that the society has of organizations at the given point in time" [22] (p. 500). Carroll [7] also constructed a very useful framework for understanding and evaluating the nature of firms' performance within these fields, called the pyramid of CSR. This pyramid bridges the gap between economic interests and other kinds of expectations. Being profitable and compliant with the law are required, whereas being ethical and being philanthropic are discretionary responsibilities that are desirable for organizations [23]. This stage of CSR concept development was characterized by the introduction of social audits, which examine the performance of companies in the areas of social responsibility with respect to communities, employees, suppliers and investors, and also to consumers in the late 1980s. In the late 1990s, social auditing was strengthened by introducing externally set and verified standards.

In the next step of development, the views on the role of CSR transformed when business analysts dealing with the problems of sustaining competitive advantage (SCA) began to recognize that CSR could be an important source of SCA. Porter and Kramer [24], representatives of the positioning view, described the methodology of selecting CSR activities, suggesting that each company should choose the issues which contribute to its competitive advantage, and include them in its strategy. Therefore, by implementing corporate social responsibility activities, companies could differentiate and reposition themselves, boost their economic returns and, as a result, gain competitive advantage $[25,26]$. The question of developing competitive advantage by CSR was also addressed by the representatives of the resource-based view (RBV) that focuses on the nature of CSR as a company's resource [27-29].

Taking stakeholders' expectations into account, CSR is presently recognized as a condition for sustainable development. It has resulted in the emergence of many international normative provisions in the field of CSR e.g., Promoting a European Framework for Corporate Social Responsibility [Green Paper] [30]. In practice, they constitute the set of rules which different organizations should incorporate on a voluntary basis when implementing the concept of corporate social responsibility. These rules help the organization to develop a corporate social responsibility strategy which contributes to sustainable development. Challenges of sustainable development like addressing climate change, environmental degradation, or poverty are among the most important goals of the CSR strategies of contemporary corporations [31]. It seems that corporations are co-opted by the state into an effort to build a global welfare state [32], which has resulted in the pressure put on them. On the other hand, the powerful players could appreciate the trend towards SD as a market opportunity. 
Nowadays, CSR is considered an important area of business activity and a strategic tool. However, due to the changes mentioned above and different perspectives taken by authors, the CSR concept is nuanced and does not have a single definition-e.g., Dahlsrud [32] indicated 37 definitions of CSR.

The most cited definition in European business literature, which is also recognized by the (p. 6) Commission of the European Communities (2001) [33], sees CSR as "a concept whereby companies integrate social and environmental concerns in their business operations and their interactions with the stakeholders on a voluntary basis". According to the European Competitiveness Report 2008 [34] (p. 109):

- $\quad$ CSR is not just philanthropy;

- interaction with stakeholders is a crucial aspect of CSR; and

- enterprises engage in the social and environmental fields more than is required by law.

According to the EU, CSR is not just philanthropy, it is business activity which should be directed towards looking for solutions which are socially acceptable, environmentally friendly, and economically sound. It is worth stressing that the new "social model" approach refers to the shaping of relations with all stakeholders, not only owners and shareholders—as in the financial approach-but also with clients, suppliers, employees, government, social institutions, and society at large.

As pointed out by Dinu [35] (p. 6), “Corporate Social Responsibility does not mean charity, nor study for the public relations department, but a smart investment, bringing benefits not only for the company, but for the entire community as well, as it contributes towards: improving the relationship with the community (clients, suppliers, authorities); influencing targeted audience, key leaders, press, etc., furnishing a real competitive edge".

Some authors $[17,26,35,36]$ claim that these views which relate CSR activities to company profitability should be called the business case for CSR and should be distinguished from CSR. They claim that CSR creates value in four ways: reducing costs and risk, creating competitive advantage, building reputation and legitimacy, and generating win-win outcomes [37]. These methods are interrelated; a good example of a win-win situation takes place in cause-related marketing, which could enhance organizational competence and contribute to its competitive advantage.

Growing interest in sustainable development (SD) has encouraged academics to research the relationships between CSR and SD [38,39]. The World Business Council for Sustainable Development, in 2000, defined CSR as business's contribution to sustainable economic development, and its commitment to increasing the quality of life of employees, their families, and society as a whole [40].

Development of CSR practices is also stimulated by institutional conditions. Within institutional theory, research is conducted mainly in two areas: macro- institutional pressures that encourage firms to engage in CSR and evidence of institutionalization [36]. The first stream of research focuses on the pressure on corporations to engage in CSR, and uses these to demonstrate how CSR varies in particular contexts [41,42].

The second stream tries to find evidence of institutionalization, such as company reports or different rules certification and norms. Bondy et al. [36] tried to find out how the CSR practices of very powerful companies, who could be considered as actors, influence the field of CSR. He suggested that MNCs are influenced to engage in CSR by two of three types of isomorphic pressures indicated by DiMaggio and Powell [43], namely coercive and mimetic. Coercive pressure comes from stakeholders; the most important are government, customers, and investors. Mimetic isomorphic pressure results from competitors. It makes companies map competitors' activities and copy them. Bondy et al. [36] investigated CSR institutions in MNCs by conveying primary research which also involved retail companies, and found six phases of the process of how the institution is organized: "one: research-where companies identified their existing CSR meanings and activities and look into competitor activity; two, strategy development-when they designed the form of their CSR commitments, including details on how it will be implemented; three, systems development-where they created or amended supporting organizational systems and relationships along with commitments 
made; four, roll-out—where strategy and systems were presented to particular groups and full scale implementation began; five; embedding, administration and review-where the most of the day to day implementation activities occurred with emphasis on the cycle of initial implementation to embodying to review of progress; six, continual involvement-where the strategy and supporting structures are revised given the feedback as obtained in the phase five".

Here, all of these views are linked to the study of stakeholders putting pressure on retail companies operating in Poland to develop CSR practices and the effect of this pressure involving inter alia codes of ethics and CSR reports. The study focuses on foreign retailers who brought their practices from well-developed markets.

\subsection{Consumers as Targets of CSR Activities}

When CSR activities are classified by targets, consumers and consumer associations are one of the most important recipients of CSR activities in the market groups; the other groups are employees, society and the environment [44]. According to Carroll [7], if the statutory regulations are not very strict and the market is not saturated, companies may seek profits by violating consumer rights. He distinguished three types of management with respect to the consumers (see Table 1):

Table 1. Types of business management with respect to consumers as CSR stakeholders.

\begin{tabular}{ll}
\hline Type of Management & Orientation Toward Customers as CSR Stakeholders \\
\hline Immoral Management & $\begin{array}{l}\text { Customers are viewed as opportunities for personal or organizational gain. } \\
\text { Ethical standards do not prevail; instead, an active intent to cheat, deceive, } \\
\text { and/or mislead is present. In all marketing decisions-advertising, pricing, } \\
\text { packaging, distribution-the customer is taken advantage of to the } \\
\text { fullest extent. }\end{array}$ \\
\hline $\begin{array}{l}\text { Management does not think through the ethical consequences of its decisions } \\
\text { and actions. It simply makes decisions with profitability within the letter of the } \\
\text { law as a guide. Management is not focused on what is fair from the perspective } \\
\text { of customers. Focus is on management's rights. No consideration is given to } \\
\text { ethical implications of interactions with customers. }\end{array}$ \\
$\begin{array}{l}\text { The customer is viewed as an equal partner in the transaction. The customer } \\
\text { brings needs/expectations to the transaction and is treated fairly. Managerial } \\
\text { focus is on giving customer fair value, full information, fair guarantee, and } \\
\text { satisfaction. Customer rights are liberally interpreted and honoured. }\end{array}$ \\
\hline
\end{tabular}

Source: [7] (pp. 39-48).

The need for practical approaches to evaluating CSR activities at the level of the whole marketplace has been put forward by The Institute of Internal Auditors [45]. They suggested taking into consideration items such as product quality and safety, responsible advertising and sales, product development and testing practices, and product stewardship and disclosure practices, which could be evaluated [45] (p. 6). Activities addressed directly to consumers involve the following [45] (p. 15):

- facilitation of customer philanthropy,

- product safety and recall processes,

- privacy of personal information/access to information,

- absence of discrimination and harassment,

- involvement of, and respect for, indigenous people,

- fair advertising,

- anti-corruption (fair competition),

- complaint management systems; consumer satisfaction.

From the perspective of stakeholder theory, consumers are important recipients of CSR practices and, thus, management's desirable behaviour and activities should aim at achieving consumer 
satisfaction. McWilliams and Siegel [46] (p. 118), pointed out that stakeholder theory has emerged as the dominant paradigm in CSR, has evolved into several new and interesting ways, and argued that investment in CSR at the firm level could be justified in terms of the respective theory that assumes that the company should maximize profits. They stressed the role of consumers by indicating two major sources of demand for CSR: consumer demand and demand from other stakeholders. Consumer demand could be driven by their attitude towards treatment of animals or their wish to have a healthy lifestyle. A company could fulfil this by offering products not tested on animals, organic and fortified food, and so on. Company investment in CSR could lead to long-term profits by differentiation from competitors.

To achieve competitive positioning, investments in research and development, as well as in checking product quality, are necessary. Another important factor of market success is investment in advertising because potential consumers have to be informed in advance about product qualities. The less developed the market is, the more investments and marketing capabilities are needed. The expenditure on advertising also depends on the type of goods offered. For search goods, less expenditure is needed than for experience goods. In the case of experience goods, such as new sorts of food, consumers are not able to determine the quality before purchase, so they rely on the brand image. CSR is a good tool for building this [47].

All of these activities are related to introducing a new product to satisfy consumer demand; additional services, such as a favourable returns policy, as well as planning advertising campaigns, are rather regular marketing activities which aim at grasping the new market segments and build consumer loyalty [48]. Here the concept of CSR is used more as a supporting idea which helps in achieving market success. The other activities indicated by [45] (p. 15), such as fair competition, are subjects of developing the institutions which will protect consumer rights.

\subsection{The Role of Institutions and Growing Competition in the Development of CSR in Retail Corporations Operating in Poland}

In modern economies, retailing is a large and dynamic sector. Retailers' attitude and involvement in CSR activities oriented towards consumers are crucial for achieving market success because retailers operate in local communities where they represent not only themselves, but also producers. The traditional view of trade units as passive intermediaries between primary producers and customers is not valid any more [49]. Nowadays, retail chains are very active in driving production and in stimulating and shaping consumer demand. They offer their own-brand products which successfully compete with national brands; moreover, in certain industries, their investment in promotion is comparable with the investment of leading manufacturers. More and more often, the goal of promotional effort is to communicate CSR and in this way, build a positive company image. They include advertising by different media, magazines edited by retailers, CSR reports, websites, as well as in-store merchandising [50]. Given the ubiquity of retailing, retailers' involvement in CSR activities towards clients appears to be a necessity.

The retail trade has an important role in the Polish economy-its contribution to GDP is about $20 \%$ [51] (p. 5), and its contribution to employment is about $15 \%$ of all employment [52] (p. 18). The contemporary landscape of Polish retailing is the result of the social and political changes of the 1990s, which introduced the liberalization of the economy. One of the first forms of non-store retailing was direct selling. Some consumers complained about the selling techniques which resulted in them buying products which were not really desired and it was publicised by the media. This situation made the Polish Direct Sales Association introduce the Direct Sales Code in 1995. The most important regulations were that the salesperson was not allowed to use confusing and unfair sales practices and that the consumer could withdraw from the agreement within 10 days of entering it. With respect to salesperson-client relationships, the Code goes much further than the binding Act of 1 July 2000 in terms of certain consumer rights, and in the area of consumers' right to return products; it guarantees rights not offered in non-direct selling agreements. 
In the mid-1990s, foreign investors started to develop new formats of store retailing: hypermarkets, discount shops, and "category killers". The chains of these mass merchandisers, on the one hand, attracted consumers with wide assortments and sales promotions, but, on the other, they sometimes violated consumer rights. This was reflected in the press, which criticized unfair practices, such as outdated goods being offered to clients, advertised products not being available, failure to comply with hygiene and safety standards, and exaggerated behaviour of security staff, such as treating clients as potential thieves [53].

The type of management introduced by foreign retailers at the early stage of their development in Poland, which sometimes lacked ethical standards in their relations with the clients, could be considered as immoral management in terms of Carroll's [7] typology. Some retailers were able to manage their companies in this way because of the high demand for retail services, low competition pressure, and an incomplete legal framework. This happened in spite of the fact that some of these practices were illegal, e.g., misleading advertising had been forbidden by the Act of 16 April 1993 on counteracting unfair competition. It resulted in ongoing criticism by the media [54].

One major problem at that time was meeting specific quality standards (which were much more restrictive for Polish products as compared with regulation abroad) and hygiene-related requirements. In 1991, the overflow of foreign, low-quality, but cheap, products, which superseded goods manufactured in Poland, prompted the government to set up The Foundation of the Polish Promotional Programme "Teraz Polska" (Now Poland) aiming at promoting domestic production.

A very important role in developing regulations to protect consumers was played by the Office of Competition and Consumer Protection (established in 1996 from the former Anti-monopoly Office). This Office elaborated the Act of 15 December 2000 on competition and consumer protection (entered into force in April 2001). The Act defined the principles of functioning of the entire system of consumer protection, in which the President of the Office takes the central position.

The need for more sustainable development was also expressed in 1999 by the setting up of the Forum Odpowiedzialnego Biznesu (Responsible Business Forum, FOB) - the organization whose mission is promoting CSR activities and sustainable development. It is a member of CSR Europe, World Business Council for Sustainable Development and United Nations Global Compact. Among many initiatives, since 2002, it has published an annual report in which the good practices of companies operating in Poland are presented.

As the process of market stabilization progressed and Polish accession to the EU became more likely, new regulations appeared. One of the most important for retailers was HACCP, implemented by the Act of 11 May 2001, on food health conditions [55]. It was followed by the Act of 27 July 2002 [56] regulating the selling and advertising process, so that consumers were not misled, and the Act of 16 February 2007 [57] on protecting competition and consumers, in which, among other things, unfair selling and promotional practices were defined.

Parallel to the development of the law, institutions protecting consumer rights were established. In addition to the Office of Competition and Consumer Protection (UOKiK), founded in 1990, whose role is to protect collective interests, consumer ombudsmen have been created in local authorities (in 2012 there were 369 such posts). UOKiK was responsible for harmonizing Polish law concerning the protection of competition and consumers with the law of the EU, which took effect when Poland joined the EU in May 2004. The individual consumer could also get help from the Association of Polish Consumers and the European Consumer Centre.

One interesting initiative towards evaluating consumer satisfaction and rewarding companies that introduce high quality standards is "Laur Konsumenta" founded in 2004. This institution aims at selecting products which have good quality, in the opinion of consumers, and are worthy of recommendation, which is given to products, but also to retailers. Examples of retailers which were granted this award include Biedronka (FMCG discounter) in 2011, Tesco (hypermarket) in 2014, Media Expert (electronics retailer) in 2013, 2015, and 2016, and Sephora (perfumery) in 2011 and 2012. 
The other institutions which were founded to encourage companies in Poland to offer good quality goods and services involve, e.g., Godło Jakości Obsługi" (Emblem for Excellent Service) and "Superbrands". "Godło Jakości Obsługi" encourages companies to improve the quality of service and has been awarded since 2008. It was awarded inter alia to Biedronka in 2010, Castorama (DIY category killer), in 2010, 2011, and 2012, and Intersport (sports goods category killer) in 2011. Superbrands is an international organization which has operated in Poland since 2002. Among those honoured by this reward in 2013 were six retail chains: four hypermarket chains (Auchan, Carrefour, Tesco, and Real) and two discounters (Biedronka and Lidl), whereas one year before there had been only two: Lidl and Ikea.

Poland's accession to the EU forced companies (especially foreign companies from the EU region, including retailers) to obey the law. The new regulations and institutions, as well as more knowledgeable consumers, forced retailers to manage companies in an amoral way which means that they did not break the law but also did not get involved very much in CSR activities. They still did not care very much about publishing reports showing their CSR involvement [54], and they only occasionally participated in national CSR initiatives.

The next stage of CSR development started at the end of the first decade of the twenty-first century. In 2007, the new law which restricted the opening of new stores by mass merchandisers in cities was introduced [58]. It was followed by a slowdown of hypermarkets' growth due to market saturation. At the same time, other retail formats, like discount stores and supermarkets, became more popular. Due to growing competition, leading retailers have increased their involvement in social responsibility practices, which is reported on their websites and communicated by mass media. Retail chains have been more visible in the annual reports prepared by FOB [59]. The focus has been on environmental issues, charity, sponsorship, and employee welfare. Although they have undertaken to create brand image and customer loyalty, consumers have not been mentioned. This is different from western economies where CSR activities aimed at consumers are stressed. A good example is the English website of Carrefour where products' safety and quality is demonstrated [60], whereas on Polish corporate websites, there is no such information [61].

Due to rigid competition and the economic crisis, a lot of retailers (small shops, retail chains targeting clients from the upper segment, and category killers in which shopping needs expertise e.g., DIY) have gone further than their legal obligations and accepted returns of goods or applied the rule of "consumer satisfaction". In this way, they tried to encourage clients to buy from them and differentiate themselves from their competitors on customer service standards.

Differentiation positioning was the main reason for offering natural and organic products. Retailers looking for new opportunities have tried to expand the trend for a healthier lifestyle and take the dominant position in this new and promising market. Examples include chains of stores specialising in organic food, as well as e-commerce retailers and mass merchandisers, which have also started to offer this kind of product. Furthermore, FMCG (fast-moving consumer goods) retailers tried to target the growing market for organic food by offering organic and fair trade products (e.g., Tesco Bio), and promoting them by exhibiting them on dedicated shelves. By these practices they have contributed to the growth of healthy lifestyle awareness in Polish society [62].

The FMCG retailer chains have also improved the quality of their own-brand products. According to a report prepared by UOKiK the standard of quality of own-brand products in the years 2008-2012 doubled [63]. In 2012, 92\% of examined foods were not complained about, whereas in 2005 the quality had been found to be low. At that time, commercial inspections found even $30 \%$ of foods in some product categories to be questionable [64].

Retail chains have tried to improve the image of these products by testing their quality and giving them certificates. For example, the leading supermarket chain in Poland-the French operator Intermarché-gave the certificate Selection to almost 1000 products in 2008-2012. Furthermore, since 2008 , consumers have been informed about the nutritional values of own-brand products by the label Dietogram [65]. Dietogram is a system which displays the portions of the most important components of 
daily nutritional requirements to consumers in an easy and transparent way using colours. This system educates consumers and helps them to make sensible choices.

The three stages in the process of development of CSR towards consumers in Poland can be identified as below (see Table 2):

Table 2. Stages of CSR towards consumer development.

\begin{tabular}{|c|c|c|c|}
\hline Period & $\begin{array}{l}\text { Prevailing Type } \\
\text { of Management }\end{array}$ & $\begin{array}{l}\text { Main Forces Fostering } \\
\text { CSR Development }\end{array}$ & Retailers' CSR Activities \\
\hline 1989-2004 & Immoral Management & $\begin{array}{l}\text { Coercive pressure coming from the } \\
\text { press, government and NGOs } \\
\text { Regulations HACCP, Institutions } \\
\text { preventing Consumers as well as } \\
\text { encouraging retailers to introduce CSR } \\
\text { practices were founded (FOB, "Teraz } \\
\text { Polska", "Laur Konsumenta" }\end{array}$ & $\begin{array}{l}\text { First Codes of Ethics } \\
\text { Some initiatives reflecting } \\
\text { CSR practices of global } \\
\text { strategy were introduced, } \\
\text { among them Avon's (direct } \\
\text { sales company) campaign }\end{array}$ \\
\hline 2005-2008 & Amoral Management & $\begin{array}{l}\text { Poland's admission to the EU, new } \\
\text { work regulations }\end{array}$ & $\begin{array}{l}\text { Retailers obey the law and } \\
\text { are more active as far as } \\
\text { participating in different } \\
\text { institutions is concerned. } \\
\text { The quality of own-brand } \\
\text { product improved. }\end{array}$ \\
\hline 2009-present & Moral Management & $\begin{array}{l}\text { Market for hypermarkets seems to be } \\
\text { saturated, new regulation limiting mass } \\
\text { merchandisers growth are introduced, } \\
\text { competition from national retailers } \\
\text { which were successful in positioning } \\
\text { themselves in the upper market } \\
\text { segments by offering very good quality, } \\
\text { natural, organic products. }\end{array}$ & $\begin{array}{l}\text { Multinational retailers } \\
\text { gradually introduce CSR } \\
\text { strategies similar to the } \\
\text { one they have in } \\
\text { well-developed countries. }\end{array}$ \\
\hline
\end{tabular}

Source: Devised by the authors.

In the first period of CSR development in Poland, although some institutions and regulations existed, there was no significant competitive pressure on retailers, so their management orientation could mostly be considered as immoral. Direct sales were an exception due to the fact that the first direct sales companies started to operate in Poland immediately after political changes, so in the middle of the nineties, they faced growing competition, whereas their methods of selling were criticized. The impact of Poland's accession to the EU had a great impact on retailers because they really had to obey the law. Additionally, new regulations protecting consumers occurred. The next stage is more difficult to identify because engagement in CSR activities depended on less obvious factors, like competition; the scope and types of CSR activities of international retailers in Poland depended on the maturity of their market. This is exemplified by the case of Tesco.

This company is one of the leaders of the FMCG market in Poland. It entered Poland in 1995 with the acquisition of Savia supermarkets, and then in 1998 it opened its first hypermarket. Due to the wide acceptance of the hypermarket format by Polish consumers, it became the main retail format in Poland. Since 2005, Savia has submitted three CSR reports to FOB, which were prepared in 2007, 2013, and 2015 [66].

In the first report, which included the years 2002-2005, the company stressed its orientation towards satisfying consumers' needs. The specific CSR activities towards consumers, which were characterized in this report, involved consumer research, company response to feedback from clients, e.g., a dedicated space for products for babies and small children because clients had signalled problems with finding them-they had been exhibited in different departments. The company stressed its policy of low prices, which was compatible with clients' expectations and new services, namely Tesco credit card and Tesco petrol stations. Most of them were just marketing activities aimed at 
improving profitability, but they were communicated to the clients as CSR. However, the company was rewarded with the "Laur Konsumenta" as the best mass merchandiser in 2005.

The next report from 2013, which covered activities for the period 2010-2012, revealed that significantly more rewards were achieved by Tesco. As far as CSR aimed at consumers is concerned, there were two worth mentioning: "Product of the Year" (awarded in 2010) and "Laur Konsumenta" (awarded in 2011). This reflected the new CSR policy towards consumers. Clients were not informed about the low prices but rather the emphasis was on quality and reasonable prices. Additionally, regional products became a very important part of the company's assortment. The company showed evidence of very strict safety control, involving such dimensions as freshness, taste, appearance, and quality. It also informed clients about their new policy of labelling their own-brand products, which included GDA (guideline daily amount) information. This policy was the first step to promoting a healthy lifestyle, which was further developed in the next report.

In this report, from 2015, along with the own-brand products targeting lower market segments and competing on price (Tesco Value and Tesco Standard) one could also find Tesco Finest and Tesco Organics competing on quality. Additionally, fair trade (FT) products were said to be included in the assortment. The company stated that, with this offer, it wanted to differentiate itself from its competitors. This report emphasised Tesco's involvement in promoting a healthy lifestyle. Accordingly, it encouraged clients to change their lifestyles to be healthier by offering good quality products at reasonable prices. The main tools to achieve this goal involved the quality programme $(100 \%$ client satisfaction), proper labelling (involving GDA indication in the case of own-brand products), expansion of the range of fruit and vegetables and healthy snacks assortment and, finally, consumer education. The company also participated in the national campaign "Read the labels-protect yourself and the world" as well as "Healthy Appetite" which is a Tesco initiative. "Healthy Appetite" is available through the company website or via the mobile application, and it suggests what a person should eat to be fit and healthy. It responds very well to the actual needs of Polish society because, in Poland, the problem of obesity (including in the case of children) has become a very important issue [62]. In the last CSR report, Tesco also emphasised its relationship with clients, which is demonstrated with quantitative and qualitative research, CSR reports, the company website and social media, its call centre, service points, special events, and Tesco magazine.

Tesco Poland's practices, which The Institute of Internal Auditors considers crucial for evaluating CSR activities aimed at consumers already discussed in this paper, were indicated in the last two reports on CSR. Moreover, it is evident that the company is trying to develop a new market segment for good quality and organic products. The last report of Tesco Poland, for which the company was rewarded by FOB, reflected its general CSR strategy described in the report from 2014-"Tesco and Society" which was aimed at, inter alia, "reducing food waste globally" and "improving health and through this, trying to tackle the global obesity crisis" [67] (p. 7). Moreover, this report was prepared according to GRI (Global Reporting Initiative) standards. Tesco also reveals how its CSR strategy was created. It involved six phases of institutionalization, from research to revision, as indicated for MNCs by Bondy et al. [36].

\section{Materials and Methods}

The research was inspired by the observation that the way in which consumers were treated by multinational companies has changed radically since the 1990s, when they started their activities in Poland. Theoretical studies on CSR towards consumers have brought the idea that Carroll's view [7] could be applied to analyse their behaviour. Accordingly, we started to seek information related to practices aimed at consumers that involve public criticism, as well as positive facts; for example, the introduction of codes of conduct. Theoretical studies have also indicated two groups of factors which could explain the change in the way retail companies are managed: competition and institutional development. The main sources of data include academic papers, reports, the Internet, and companies' 
websites. Their selection was influenced by the authors' knowledge and experiences while researching CSR in retailing, which also involved seminars and meetings with business people.

Table 2 shows the changes in the way the big retailers are managed have a few weaknesses. The first is that not all multinational chains were criticized-mostly they were direct-selling companies, hypermarkets, and discount stores. The second is related to the specified time periods. In the first one described as "immoral", some criticized retailers recognized the problem and implemented standards directed towards recovering their relationships with clients. Therefore, these periods should be treated as contractual, although they reflect the general trend of the development of CSR practices towards consumers and it should be stressed that Poland's accession to the EU really had a great impact on them because it forced European retailers to obey the law.

In this research, the longitudinal case study of Tesco is also presented. This company was chosen because it is one of the leading retail companies in Poland, which has been present in Poland for a long time, and it was rewarded for its CSR practices since 1991 by FOB in 2015 and, most importantly, it has regularly published CSR reports since 2005, which made comparison possible.

Research limitations stem from the fact that in the analysed period (1989-2016), the Polish economy has been in transition. As a consequence, it is not possible to acquire regular and adequate data from retailers because they do not report their CSR activities on a regular basis. Even if they provide information about them, CSR aimed at consumers is mentioned very rarely. Consequently, the authors have had to identify some data from more general information. This also implies that the research is based on examples and a case study and has a descriptive character. However, in our opinion the evidence does help to answer the questions which were put forward and confirm some views presented in the theoretical section.

In the future, it will be interesting to investigate whether multinational retailers, such as Tesco, adjust their CSR practices to the foreign market in which they operate or rather consider them as routines which contribute to their SCA, identifying if there are routines which change existing CSR practices, how these practices affect the market, and so on. To convey such research, secondary and primary information from several markets are necessary. Their results could fill the gap that exists (in our opinion) in the theory concerning the contribution of CSR routines to SCA development.

\section{Conclusions}

Retailers' attitudes towards the implementation of CSR aimed at consumers is of great importance due their proximity to consumers and their position in distribution channels-behaving in unethical ways could spoil not only their image and sales, but also have an adverse effect on sales for manufacturers. Companies organized as chains often extend their scope of liability by offering their own-brand products and supervise the supply chain to ensure their quality.

The case of Poland shows that as far as large, international retail companies are concerned, CSR applied on a voluntary basis is a myth. When the market was not saturated, and there were no strict statutory regulations, or institutions protecting consumers from unfair practices, and consumers were not educated, international retailers did not take care of them although, at the same time, they applied CSR in the host markets. This justifies Carroll's [7] statement.

Coercive pressure was a very important factor in the change from immoral to amoral management behaviour. The most important were changes in the law backed by the authority of the EU. To avoid public criticism and lawsuits, companies changed their attitude towards consumers but very rarely did they do more than they were required to in order to demonstrate that they were really socially responsible.

Growing competition forced retailers to build a positive image and look for the possibilities of differentiating themselves from their competitors. Leading Polish retail chains, responding to environmental changes, not only tried to assure good quality products, fair selling and advertising practices, as suggested by the stakeholder theory, but also targeted new market segments by offering 
fair trade and organic products. This is consistent with shareholders' view and Porter and Kramer's view [24] that social responsibility could be a foundation of a competitive strategy.

The fact that multinational retailers started to implement CSR standards when facing growing competition suggests that their attitude should be classified as a business case for CSR. This raises the question of whether activities should not rather be considered as a part of societal marketing. Societal marketing is defined as "delivering to the target consumers superior value in a way that maintains or improves the consumer's and the society's well being" [68] (p. 19). Marketing activities should be conducted in a way which does not contribute to contemporary problems e.g., environment degradation or resource shortages. The company, by its marketing activities, should not only satisfy short-term consumers' wants, but also take care of long-term consumers' welfare. The concepts of CSR aimed at consumers and societal marketing seem to be closely related and both contribute to sustainable development.

The comparison conveyed here has shown that standards which have been put forward by the Institute of Internal Auditors have become the norm when retailers communicate their activities to the public. They also follow the standard of CSR strategy development described by Bondy et al. [37]. Therefore, these institutions provide multinational retailers with a direction for CSR development. The other institutions like FOB, "Laur Konsumenta", "Product of the Year", Superbrand, or "Godło Jakość Obsługi" reflect important social issues. The fact that retailers are more interested in participating in these initiatives means that they are increasingly aware of the importance of their image and how it could influence their profitability.

Multinational retailers replicate their CSR activities in various markets in which they operate, but their character and scope depends on foreign market maturity; for example, the well-known initiative "Tesco for Schools" was introduced in Poland in 2002 (a full ten years after it started in Great Britain). If these initiatives contribute to the companies' profitability, they can be treated as assets, which differentiate a given retailer from its competitors.

Despite the motives for implementing CSR standards by the multinational retailers, they contribute to sustainable development, which is very important in emerging markets like Poland. As far as CSR towards consumers is concerned, some standards implemented by the multinational retailers preceded the law. These companies also educate consumers and improve their living standards by giving them access to good quality, organic, bio, and FT products at reasonable prices.

Acknowledgments: We would like to thank Marie-France Turcotte for some ideas brought during the discussion within the CSR session on ASAC conference 2015.

Author Contributions: Designing and performing the research Grażyna Śmigielska and Renata Oczkowska; writing the paper and analyzing data-Grażyna Śmigielska. All authors read and approved the final manuscript.

Conflicts of Interest: The authors declare no conflict of interest.

\section{References}

1. Brundtland Report 1987. Available online: http://www.channelingreality.com/Documents/Brundtland_ Searchable.pdf (accessed on 3 March 2015).

2. Dąbrowska, A.; Bylok, F.; Janoś-Kresło, M.; Kiełczewski, D.; Ozimek, I. Consumer Competencies-Innovative Behaviour, Sustainable Consumption; PWE: Warszawa, Poland, 2015.

3. Nielsen Raport on Sustaiability. The Sustainability Imperative. 2015. Available online: http://www.nielsen. com/content/dam/nielsenglobal/dk/docs/global-sustainability-report-oct (accessed on 2 March 2015).

4. Baechler, N. Does sustainable development make good strategies for corporate actors? İktisadi ve İdari Bilimler Dergisi 2016, 38, 57-72. [CrossRef]

5. Sahlin-Andersson, K. Corporate social responsibility: A trend and a movement, but of what and for what? Corp. Gov. Int. J. Bus. Soc. 2006, 6, 595-608. [CrossRef]

6. Blowfield, M.; Frynas, J.G. Editorial Setting new agendas: Critical perspectives on Corporate Social Responsibility in the developing world. Int. Aff. 2005, 81, 499-513. [CrossRef] 
7. Carroll, A.B. The Pyramid of Corporate Social Responsibility: Toward the Moral Management of Organizational Stakeholders. Bus. Horiz. 1991, 34, 39-48. [CrossRef]

8. Carroll, A.B. Ethical challenges for business in the new millennium: Corporate social responsibility and models of management morality. Bus. Ethics Q. 2000, 10, 33-42. [CrossRef]

9. Carroll, A.B.; Shabana, K.M. The business case for corporate social responsibility: A review of concepts, research and practice. Int. J. Manag. Rev. 2010, 12, 85-105. [CrossRef]

10. Husted, B.W.; Allen, D.B. Corporate social strategy in multinational enterprises: Antecedents and value creation. J. Bus. Ethics 2007, 74, 345-361. [CrossRef]

11. Cruz, L.B.; Boehe, D.M. How do leading retail MNCs leverage CSR globally? Insights from Brazil. J. Bus. Ethics 2010, 91, 243-263. [CrossRef]

12. Moreno, A.; Capriotti, P. Communicating CSR, citizenship and sustainability on the web. J. Commun. Manag. 2009, 13, 157-175. [CrossRef]

13. Pettigrew, A.M. Longitudinal field research on change: Theory and practice. Organ. Sci. 1990, 1, $267-292$. [CrossRef]

14. Sadler, D. Anti-corporate Campaigning and Corporate Social Responsibility: Towards Alternative Spaces of Citizenship? Antipode 2004, 36, 851-869. [CrossRef]

15. Bowen, H.R. Social Responsibility of the Businessman; Harper \& Row: New York, NY, USA, 1953.

16. Friedman, M. Capitalism and Freedom; University of Chicago Press: Chicago, IL, USA, 1962.

17. Friedman, M. The Social Responsibility of Business Is to Increase Its Profits. New York Times Magazine, 13 September 1970.

18. Levitt, T. The dangers of social responsibility. Harv. Bus. Rev. 1958, 36, 41-50.

19. Freeman, E. Strategic Management. A Stakeholder Approach; Pitman: Boston, MA, USA, 1984.

20. Donaldson, T.; Preston, L.E. The stakeholder theory of the Corporation. Concepts, evidence and implications. Acad. Manag. Rev. 1995, 20, 65-91.

21. De Wit, B.; Meyer, R. Strategy, 2nd ed.; International Thomson Business Press: London, UK, 1998.

22. Carroll, A.B. The three-dimensional conceptual model of corporate social performance. Acad. Manag. Rev. 1979, 4, 497-505.

23. Schwartz, M.S.; Carroll, A.B. Corporate Social Responsibility: A Three-Domain Approach. Bus. Ethics Q. 2003, 13, 503-530. [CrossRef]

24. Porter, M.E.; Kramer, M.R. Strategy and Society. The Link between Competitive Advantage and Corporate Social Responsibility. Harv. Bus. Rev. 2006, 84, 78-91. [PubMed]

25. Schaltegger, S.; Synnestvedt, T. The link between 'green' and economic success: Environmental management as the crucial trigger between environmental and economic performance. J. Environ. Manag. 2002, 65, 339-346.

26. Porter, M.E.; Kramer, M.R. The Big Idea: Creating Shared Value, Rethinking Capitalism. Harv. Bus. Rev. 2011, $89,62-77$.

27. Dennis, B.; D'Intino, R.S.; Houghton, J.D.; Neck, C.P.; Boyles, T. Corporate social performance: Creating resources to help organizations excel. Glob. Bus. Organ. Excell. 2008, 27, 26-41. [CrossRef]

28. Falkenberg, J.; Brunsael, P. Corporate social responsibility: A strategic advantage or a strategic necessity? J. Bus. Ethics 2011, 99, 9-16. [CrossRef]

29. Heikkurinen, P.; Forsman-Hugg, S. Strategic corporate responsibility in the food chain. Corp. Soc. Responsib. Environ. Manag. 2011, 18, 306-316. [CrossRef]

30. Kwarcińska, A. Międzynarodowe inicjatywy normatywne w zakresie społecznej odpowiedzialności biznesu (CSR) jako wyraz działań na rzecz zrównoważonego rozwoju. Prace Naukowe Uniwersytetu Ekonomicznego we Wroctawiu 2016, 416, 95-103.

31. Płachciak, A. Znaczenie społecznej odpowiedzialności biznesu we wdrażaniu rozwoju zrównoważonego. Res. Pap. Wroclaw Univ. Econ./Prace Naukowe Uniwersytetu Ekonomicznego we Wroclawiu 2015, 378, 168-177. [CrossRef]

32. Dahlsrud, A. How corporate social responsibility is defined-An analysis of 37 definitions. Corp. Soc. Responsib. Environ. Manag. 2008, 15, 1-13. [CrossRef]

33. Commission of the European Communities. Promoting a European Framework for Corporate Social Responsibility, Green Paper. 2001. Available online: http:/ /europa.eu/rapid/press-release_DOC-01-9_en. pdf (accessed on 21 August 2016). 
34. Commission of the European Communities. European Competitiveness Report 2008. 2009. Available online: http:/ / bookshop.europa.eu/en/european-competitiveness-report-2008-pbNBAK08001/ (accessed on 21 August 2016).

35. Dinu, V. Corporate Social Responsibility-Opportunity for Reconciliation between Economical Interests and Social and Environmental Interests. Amfiteatru Econ. J. 2011, 29, 6-8.

36. Bondy, K.; Moon, J.; Matten, D. An institution of corporate social responsibility (CSR) in multi-national corporations (MNCs): Form and implications. J. Bus. Ethics 2012, 111, 281-299. [CrossRef]

37. Kurucz, E.C.; Colbert, B.A.; Wheeler, D. The business case for corporate social responsibility. In The Oxford Handbook of Corporate Social Responsibility; Crane, A., McWilliams, A., Matten, D., Moon, J., Siegel, D., Eds.; Oxford University Press: Oxford, UK, 2008; pp. 83-112.

38. Steurer, R.; Langer, M.E.; Konrad, A.; Martinuzzi, A. Corporations, stakeholders and sustainable development I: A theoretical exploration of business-society relations. J. Bus. Ethics 2005, 61, 263-281. [CrossRef]

39. Ebner, D.; Baumgartner, R.J. The relationship between sustainable development and corporate social responsibility. In Proceedings of the Corporate Responsibility Research Conference 2006, Dublin, Ireland, 4-5 September 2006; Volume 4. No. 5.9.

40. Kärnä, J.; Hansen, E.; Juslin, H. Social responsibility in environmental marketing planning. Eur. J. Mark. 2003, 37, 848-871. [CrossRef]

41. Doh, J.P.; Guay, T.R. Corporate social responsibility, public policy, and NGO activism in Europe and the United States: An institutional-stakeholder perspective. J. Manag. Stud. 2006, 43, 47-73. [CrossRef]

42. Avetisyan, E.; Ferrary, M. Dynamics of Stakeholders' Implications in the Institutionalization of the CSR Field in France and in the United States. J. Bus. Ethics 2013, 115, 115-133. [CrossRef]

43. DiMaggio, P.; Powell, W.W. The iron cage revisited: Collective rationality and institutional isomorphism in organizational fields. Am. Sociol. Rev. 1983, 48, 147-160. [CrossRef]

44. Mandl, I.; Dorr, A. CSR and Competitiveness: European SMEs' Good Practice-Consolidated European Report. 2007. Available online: https://pdfs.semanticscholar.org/e696/8d6486052d4db808 2416c0e73a5ac8777d75.pdf (accessed on 20 August 2014).

45. Morley, L.C.; Balza, C.R.; Zechnich, D.W. (Practice Guide) Evaluating Corporate Social Responsibility/ Sustainable Development. 2010. Available online: http://www.iiacolombia.com/resource/guias/ Evaluating\%20Corporate\%20-\%20Feb\%202010.pdf (accessed on 20 August 2014).

46. McWilliams, A.; Siegel, D. Corporate Social Responsibility: A Theory of the Firm Perspective. Acad. Manag. Rev. 2001, 26, 117-127.

47. Popoli, P. Linking CSR strategy and brand image. Different approaches in local and global markets. Mark. Theory 2011, 11, 419-433. [CrossRef]

48. Oczkowska, R.; Śmigielska, G. Marketing Strategies of Retailers in Poland: How CSR Activities Fit. In Dilemas of the Contemporary Economy Facing Global Changes; Kaczmarek, J., Rojek, R., Eds.; Foundation of the Cracow University of Economics: Cracow, Poland, 2012; pp. 297-510.

49. Jones, P.; Comfort, P.; Hillier, D.; Eastwood, J. Retailers and sustainable development in the UK. Int. J. Retail Distrib. Manag. 2005, 33, 207-214. [CrossRef]

50. Stefańska, M. Komunikacja marketingowa a społeczna odpowiedzialność handlu, (Marketing communication abnd corporate social responsability of trade companies). Handel Wewnętrzny 2012, 2, $14-22$.

51. Faliński, M.A. Rola handlu w polskiej transformacji gospodarczej. In Znaczenie Handlu w Gospodarce Narodowej; POHiD, GFL: Warszawa, Poland, 2014; pp. 4-6. Available online: http://eregion.wzp.pl/ sites/default/files/znaczenie_handlu_w_gospodarce_narodowej.pdf (accessed on 23 September 2016).

52. Kłosiewicz-Górecka, U. Handel jako pracodawca. In Znaczenie Handlu w Gospodarce Narodowej; POHiD, GFL: Warszawa, Poland, 2014; pp. 18-23. Available online: http://eregion.wzp.pl/sites/default/files/znaczenie_ handlu_w_gospodarce_narodowej.pdf (accessed on 23 September 2016).

53. Szewczyk, R. Zarabianie na zła sławę (Formation of bad immage). Mark. w Praktyce 2002, 3, $25-28$.

54. Oczkowska, R.; Śmigielska, G. Social Responsibility of International Retail Chain in Poland. In Proceedings of the 9th International Conference Marketing Trends, Venice, Italy, 21-23 January 2010. Available online: http://www.marketing-trends-congress.com/archives/2010/Materiali/Paper/Fr/Oczkowska_ Migielska.pdf (accessed on 12 December 2016). 
55. Głodkowski, O.; Malinowski, B.; Wójcik, A. HCCP w Handlu Detalicznym; PARP: Warszawa, Poland, 2004. Available online: http:/ / www.carsekt.pl/pobierz/haccp(3).pdf (accessed on 8 March 2015).

56. Ustawa z Dnia 27 Lipca 2002 Roku o Szczególnych Warunkach Sprzedaży Konsumenckiej Oraz o Zmianie Kodeksu Cywilnego. Available online: http://www.konsument.gov.pl/uploads/File/Ustawy/Ustawa\% 20o\%20szczegolnych\%20warunkach\%20sprzedazy\%20konsumenckiej.pdf (accessed on 8 March 2015).

57. UOKiK. Ustawa z Dnia 16 Lutego 2007 Roku o Ochronie Konkurencji i Konsumentów. Available online: https:/ / uokik.gov.pl/download.php?id=1258 (accessed on 8 March 2015).

58. Stefańska, M.; Pilarczyk, B. Retail marketing strategies-Evolution and the future of retail companies in Poland. In Proceedings of the 9th International Conference Marketing Trends, Venice, Italy, 21-23 January 2010; Andreani, J.-C., Collesei, U., Eds.; Paris-Venice Marketing Trends Association; pp. 1-20. Available online: www.marketing-trends-conference.com (accessed on 7 June 2014).

59. Forum Odpowiedzialnego Biznesu. Responsible Business Forum. Available online: http:// odpowiedzialnybiznes.pl/en/about-us.html (accessed on 12 August 2016).

60. Carrefour 1. Available online: http://www.carrefour.net/en/articles.html?t=31 (accessed on 12 August 2016).

61. Carrefour 2. Available online: http://www.carrefour.pl/serwis-korporacyjny (accessed on 12 August 2016).

62. Śmigielska, G.C. Challenges for the Trade in Central and Southeast Europe; Series International Business \& Management; Renko, S., Knezevic, B., Eds.; Emerald Group Publishing Limited: Bingley, UK, 2013; Volume 29, pp. 55-71.

63. UOKiK. Available online: http://www.uokik.gov.pl/produkty.php (accessed on 12 August 2016).

64. MGIP. Raport o Stanie Handlu Wewnętrznego w 2004r. 2005. Available online: www.mg.gov.pl/NR/ rdonlyres/01E05417/handel_wew_2005r.pdf (accessed on 12 August 2016).

65. Dietogram. Available online: www.muszkieterowie.pl/index.php?option=com_content\&view=article\&id= 125:dietogram-i-wiesz-co-jesz\&catid=45:aktualnoci-2008\&Itemid=114 (accessed on 10 August 2010).

66. Raporty Spoleczne. Available online: http://raportyspoleczne.pl/bibliotekaraportow / ?organizacja=56\& industries=\&title_term=\&edycja=\&filtered=yes (accessed on 12 December 2016).

67. Tesco. Tesco and Society_Report 2014. Available online: https://www.tescoplc.com/media/1184/tesco_ and_society_review_2014.pdf (accessed on 12 August 2015).

68. Kotler, P.; Armstrong, G. Principles of Marketing, 7th ed.; Prentice Hall International Inc.: Upper Saddle River, NJ, USA, 1996.

(C) 2017 by the authors; licensee MDPI, Basel, Switzerland. This article is an open access article distributed under the terms and conditions of the Creative Commons Attribution (CC-BY) license (http://creativecommons.org/licenses/by/4.0/). 